\title{
ASSESSMENT OF THE RELIABILITY-COST EFFICIENCY OF THE PUMPING SUBSYSTEMS AT WATER TREATMENT PLANT
}

\author{
OCENA NIEZAWODNOŚCIOWO-KOSZTOWA EFEKTYWNOŚCI \\ FUNKCJONOWANIA POMPOWNI W STACJI UZDATNIANIA WODY
}

\begin{abstract}
In last years all countries of the European Union experience decrease of water consumption. What is worse, in most cases large European water treatment plants (WTP) have been design and built decades ago, when water consumption was much higher than nowadays. It is a challenging task to adjust WTP's capacity to the current water demand as it is associated with costs and safety issues. Minding that fact, authors decided to propose an new authorial methodology of combined reliability-cost efficiency assessment for water supply system with exceeded redundant capacity, based on new index - unit indicator of reliability-cost efficiency. It included both reliability and costs aspects. It was decided to present the new method on example of the pumping subsystems working for WTP in Poland. The research was based on Activity-Based Life Cycle Costs (AB-LCC) methodology together with two-parametric reliability evaluation. Using real operational and financial data an application of proposed authorial reliability-cost indicator was presented. The reliability-cost efficiency assessment allowed to present how operation of each pumping subsystem influenced global operational costs of WTP. This information is essential for decision-making process for rational management of technical facilities.
\end{abstract}

Keywords: water supply system, water treatment plant, pumping systems, reliability, Life Cycle Cost $(L C C)$, operational costs

\section{Introduction}

Water treatment plants (WTP) supplying big Polish cities in most cases purify surface water from lakes and rivers. They have been design and built many decades ago, when water consumption was much higher than nowadays and when political conditions were not encouraging to find the most cost effective technical solution. Times have changed and now, after 25 years since market economy principles have been introduced in the Polish water supply sector, all countries of the European Union (including Poland) experience decrease of water consumption [1,2]. Moreover, EU expects high standards for drinking water quality what also influences water treatment plants' operation. To ensure required water quality, in many WTPs new subsystems have been provided eg ozonation, sorption etc. However, adjusting plant's production capacity to the current demand and bearing the

\footnotetext{
${ }^{1}$ Institute of Water and Wastewater Engineering, Silesian University of Technology, ul. S. Konarskiego 18, 44-100 Gliwice, Poland, phone +48 3223716 98, fax +48 322371047

*Corresponding author: izabela.zimoch@polsl.pl
} 
lowest possible costs is much more complicated process and it requires various analysis including assessment of costs efficiency and reliability [3-14].

\section{Aim and scope of the research}

In order to present authors' new methodology of combined reliability-cost efficiency assessment, authors decide to show it on example of two operating pumping stations (subsystems) working for WTP in Southern Poland. The purpose of this study is to evaluate how operation of each pumping station influenced global operational costs of treatment of $1 \mathrm{~m}^{3}$ of water.

The scope of the research includes calculation of basic reliability factors ie average operating time between failures \& readiness indicator, investigating all cost of pumps' life cycle and application of proposed authorial new reliability-cost index.

All calculations are based on operational and financial data for the period of last 8 years.

\section{Applied methodology}

\section{Reliability calculation method}

Reliability analysis is based on collected exploitation data. The analysis includes data related to pumps renewals and maintenance $i e$ date of failure, renewal or inspections occurrence and date of its closure. The reliability indicators for each pump are calculated according to following formulas $[3,10,15]$ :

a) average operating time between failures $T_{p}$ :

$$
T_{p}=\frac{1}{n_{p}}\left(T-\sum_{i=1}^{n_{o}} t_{n i}\right)
$$

b) readiness indicator $K$ :

$$
K=\frac{T_{p}}{T_{p}+T_{n}}
$$

where $n_{p}$ is number of segments of working periods in analysed period [-], $n_{o}$ is number of renewals in analysed period [-], $t_{n i}$ is a duration of " $i$ " renewal [h], $T$ is analysed period duration [h], $T_{n}$ stands for average renewal time [-].

According to the literature [3, 10, 16-19] the values of readiness indicator are calculated to seven decimal places [15].

\section{Costing model}

To determinate which type of cost analysis is the most adequate for the WTP, different models were taken into consideration. As combined reliability and economic research for municipal systems is a novel approach, authors reviewed literature from other technical sectors such as mining industry [20] and energetic [21]. It is assumed that Life Cycle Costing ( $L C C$ [PLN]) was the most applicable [22-31]. LCC analysis takes into account all costs incurred during the technical life cycle of an object. This model is usually described with the following equation [26-28]: 


$$
L C C=C_{d}+C_{b}+C_{u}+C_{d i}
$$

where: $C_{d}$ - costs of design phase [PLN], $C_{b}$ - costs of construction phase [PLN], $C_{u}$ - costs of usage phase [PLN], $C_{d i}$ - costs of disposal phase [PLN].

Costs of design, construction and disposal were relatively easy to define, however costs related to the usage phase are much more difficult to investigate. As usage phase lasts the longest many maintenance actions are then carried out, and moreover, values of costs are different because of the change of the money value over the time. To make sure that all indirect costs are included in usage phase costs, LCC model was expanded and Activity Based Life Cycle Costing (AB-LCC) model is finally applied [22-28]. This method assigns indirect overhead and activity costs to the analysed objects and uses "cause - effect" relations between factors that generate costs and activities. In other words this concept allowed costs grouping by actions which are actual causes of cost. For pumping subsystems the actions which cause costs are; maintenance works and repair or replacement of failed equipment. The AB-LCC model includes costs related to used materials (eg spare parts, lubricating oil), labour and energy.

In accordance with Polish legislation acts for investor's costing, it is assumed that design costs equal $5 \%$ of the construction costs. This LCC phase included costs related to the provision of executive design, land surveys and obtaining all required permits.

Costs of construction phase are estimated in accordance with Polish legislation ie using average published values of costs in 2015. The following particular aspect are taken under consideration; cost of construction and installation works, installed equipment, direct used materials and direct labour costs.

According to AB-LCC model, usage phase costs are being generated during maintaining and repair activities. It was decided that in presented research comparable time horizon is 30 years. The scope of the research includes calculation of usage phase cost for pumps \& electric engines as well as inlet chambers and building construction. Using data obtained from professional contractors, it is assumed that the concrete surface will require repairs once every 20 years with an average costs of $30 \%$ of construction. What is more, each chamber is cleaned once a year and this action results in costs of labour, materials and overheads. This is calculated basing on data obtained at the plant. The cost of possible repairs is determined basing on information and calculation of the professional contractor who carries out these works.

Finally, disposal phase is related to cost of dismantling works and waste disposal. In case of pumps and engines profit from the sale of dismantled scrap metal is significant so it is included in the research.

What is more, proposed calculation method includes the change of the money value over the time. All costs in the research are discounted and the equation below shows the relation between the future and present value of money $[4,26]$ :

$$
P V=\frac{F V}{(1+r)^{t}}
$$

where: $P V$ - present value of cost [PLN], $F V$ - future value of cost [PLN], $r$ - discount rate [-], $t$ - discount period [-].

According to "Guide to Cost-Benefit Analysis of Major Projects in the context of EC Regional Policy" by European Commission [32] " $r$ " factor for Poland equals 0.05. 
AB-LCC model directly refers to costs, however from economic point of view, equation (3) can be a sum of cash flows $(C F)$ ie the incoming and outgoing of cash, representing the operating activities of a water supply company [26, 27]. Cash flows can be divided into cash outlays eg for design, construction, usage of an object and cash income profit from the sale of dismantled scrap metal. The total value of each life phase is a balance of occurred cash flows.

Taking into consideration, that the $L C C$ equals discounted balance of all cash flows eg Present Value of Cash Flow $(P V C F)$ for Life Cycle Costs can be presented by the following formula [21-26]:

$$
L C C_{j}=P V C F=\sum_{t=0}^{n} \frac{C F_{t}}{(1+r)^{t}}
$$

where: $L C C_{j}$ - Life Cycle Costs for “j” object [PLN], PVCF - Present Value of Cash Flow [PLN], $C F_{t}$ - net Cash Flows in " $t$ " period [PLN], $r$ - discount rate [-], $t$ - discount period [-].

\section{Combined reliability-cost efficiency analysis}

Proposed analysis equally includes reliability of pumping subsystems' operation and the costing aspect. In order to ease the interpretation, the authors propose new index ie unit indicator of reliability-cost efficiency $\left(I_{r c e}\right)$ represented by the formula:

$$
I_{r c e}=\frac{L C C_{i} \cdot K_{i}}{P \cdot Q_{i}}
$$

where: $L C C_{i}$ - Life Cycle Costs for " $i$ " pumping subsystem [PLN], $K_{i}$ - readiness indicator for “ $i$ " pumping subsystem, $Q_{i}$ - analysed “ $i$ " subsystem's efficiency which occurs with probability $P=0.99$.

This indicator describes how the costs $\left(L C C_{i}\right)$ and reliability $\left(K_{i}\right)$ influence the global cost of $1 \mathrm{~m}^{3}$ of treated water.

It is obvious that reliability and costs are closely related. That is the reason why both of these aspects were included equally in the numerator of the equation (6). In the same time, the denominator refers to pumping subsystem efficiency. This allows to compare pumping subsystems with different daily efficiency. Since analysed subsystems are considered as system with redundant capacity, it is important to analyse the real subsystem efficiency occurred in the last 8 years. Basing on statistical assumptions, it was establish that water system's efficiency which occurs with probability $P=0.99$ and less (percentile of 99\%) will be adequate for the analyse purposes.

\section{Brief description of analysed WTP}

The pumping stations are part of the WTP which is a one of eleven local water delivery systems and provides water to more than 3 million Silesian citizens. The WTP purifies water from two independent lakes. From the first one, water is transported by gravity, from second - thanks to first stage pumping station. In order to present the new approach in more comprehensible manner, this subsystem was named "Pumping subsystem A".

The water is being treated in two parallel treatment subsystems. Both include pre-ozonation, coagulation (with aluminium sulphate), sedimentation and filtration. Then 
thanks to transitional pumping station water is being transported, via a transitional ozonation subsystem, to the active carbon filtration building and finally to the reservoirs, where it is subjected to disinfection with chlorine. The transitional pumping station receives water from both subsystems. The water being fully mixed before being forwarded to carbon filters and then to the reservoirs. The transitional pumping is the second analysed pumping subsystem. In order to present the new approach in more comprehensible manner, this subsystem was named "Pumping subsystem B".

\section{Pumping subsystem A}

This subsystem is one of the oldest objects of WTP. It has been operating for more than 60 years now. Its design capacity equals $350000 \mathrm{~m}^{3}$ per day. There are two independent buildings equipped with 4 pumps each.

Water is pumped from first building to a distribution chamber, from where it flows to process line I. In contrast, water from the second building is fed by gravity from the second source, and then flows to process line II. In exceptional situations, process line II can be supply by process line I through the so-called emergency pipeline (Fig. 1). The amount of the water which is subject to treatment, is determined by its quality in the both sources.

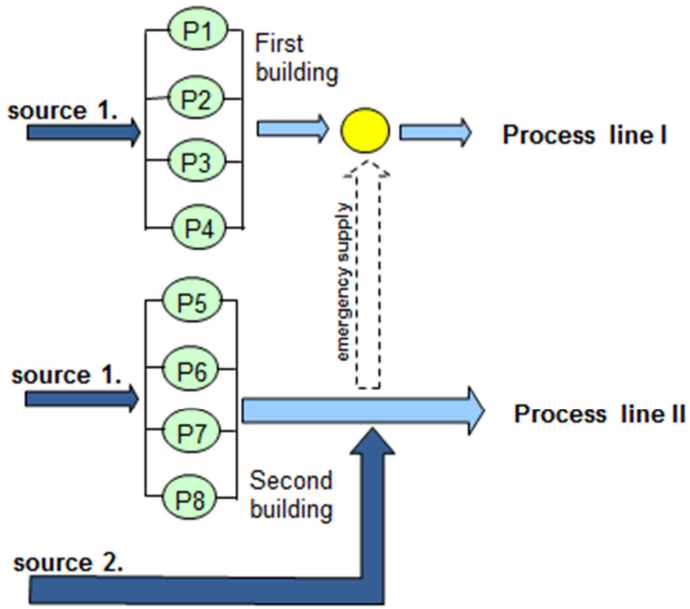

Fig. 1. Flow diagram of Pumping subsystem A

Basing on actual values of subsystem's efficiency registered in last 8 years, the descriptive statistics are determined (Table 1).

Table 1

Descriptive statistics of Pumping subsystem A efficiency

\begin{tabular}{|c|c|c|c|c|}
\hline Efficiency variables & $\begin{array}{c}\text { Average } \\
{\left[\mathbf{m}^{\mathbf{3}} / \mathbf{d}\right]}\end{array}$ & $\begin{array}{c}\text { Median } \\
{\left[\mathbf{m}^{\mathbf{3}} / \mathbf{d}\right]}\end{array}$ & $\begin{array}{c}\text { Maximum } \\
{\left[\mathbf{m}^{\mathbf{3}} / \mathbf{d}\right]}\end{array}$ & $\begin{array}{c}\text { Percentile of 99\% } \\
{\left[\mathbf{m}^{\mathbf{3}} / \mathbf{d}\right]}\end{array}$ \\
\hline Pumping subsystem A & 77298 & 80100 & 239600 & 207500 \\
\hline
\end{tabular}

Moreover, the distribution of variables is investigated. The analysis included testing of the hypothesis of normal distribution of efficiency variables (Fig. 2). The statistical tests of 
Kolmogorov-Smirnov (KS) and $\chi^{2}$ are applied. Standard level of significance $(\alpha=0.01)$ is adopted in this study.

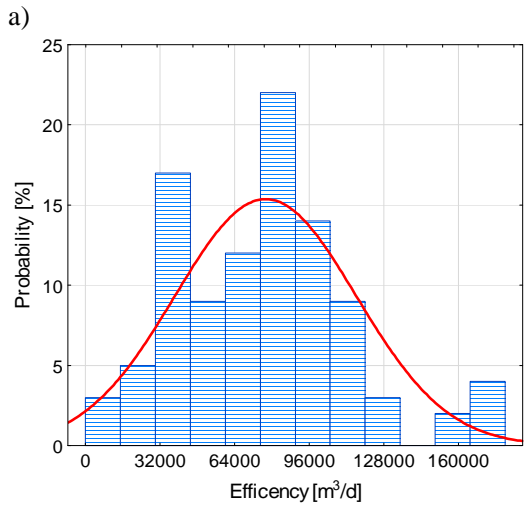

b)

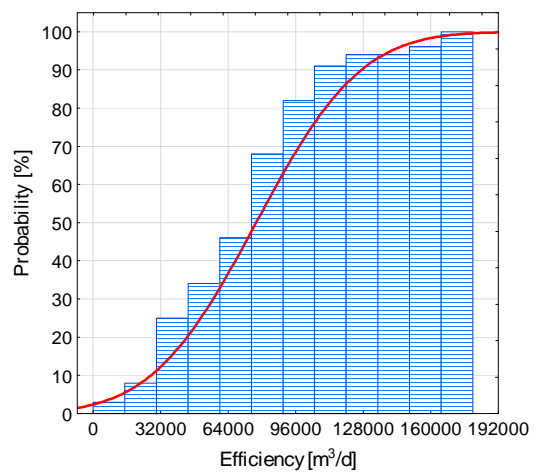

Fig. 1. Normal distribution of Pumping subsystem A efficiency: d Kolmogorov-Smirnov 0.05842, $p=0.03590$ : a) distribution of Pumping subsystem A efficiency, b) empirical cumulative distribution of Pumping subsystem A efficiency

Basing on the obtained results, it was established that representative efficiency for the last years (occurs with probability 0.99 ) equals $207500 \mathrm{~m}^{3} / \mathrm{d}$.

\section{Pumping subsystem B}

This subsystem is the youngest objects of analysed WTP (Fig. 3). It has been operating since 2004. Its design capacity equals $500000 \mathrm{~m}^{3} / \mathrm{d}$. Basing on actual values of subsystem's efficiency registered in last 8 years, the descriptive statistics are determined (Table 2).

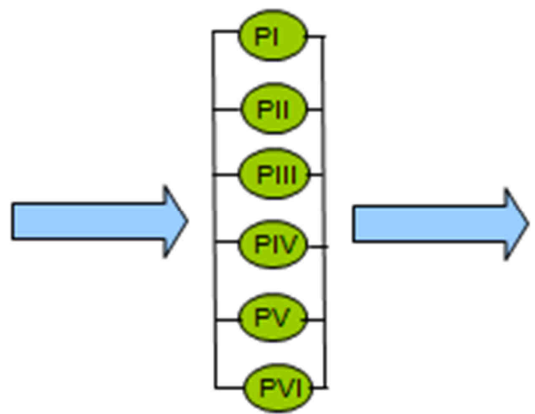

Fig. 3. Flow diagram of Pumping subsystem B

Descriptive statistics of Pumping subsystem B efficiency

\begin{tabular}{|c|c|c|c|c|}
\hline Efficiency variables & $\begin{array}{c}\text { Average } \\
{\left[\mathbf{m}^{\mathbf{3} / \mathbf{d}]}\right.}\end{array}$ & $\begin{array}{c}\text { Median } \\
{\left[\mathbf{m}^{\mathbf{3}} / \mathbf{d}\right]}\end{array}$ & $\begin{array}{c}\text { Maximum } \\
{\left[\mathbf{m}^{3} / \mathbf{d}\right]}\end{array}$ & $\begin{array}{c}\text { Percentile of 99\% } \\
{\left[\mathbf{m}^{\mathbf{3}} / \mathbf{d}\right]}\end{array}$ \\
\hline Pumping subsystem B & 224334 & 223600 & 344700 & 308400 \\
\hline
\end{tabular}


Analogical as for Pumping subsystem A, the distribution of variables is investigated. The analysis included testing of the hypothesis of normal distribution of efficiency variables (Fig. 4). The statistical tests of Kolmogorov-Smirnov (KS) and $\chi^{2}$ are applied with standard level of significance $(\alpha=0.01)$.

a)

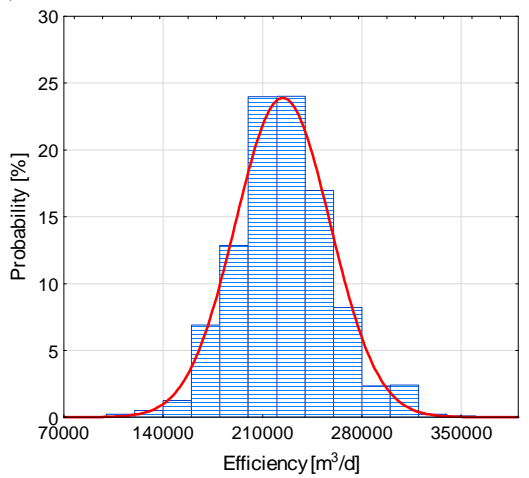

b)

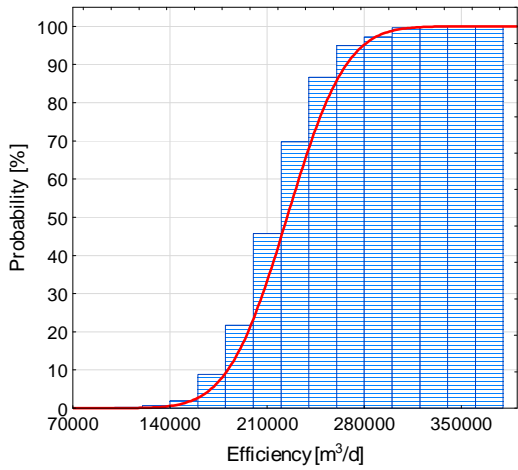

Fig. 4. Normal distribution of Pumping subsystem B efficiency: d Kolmogorov-Smirnov 0.03103, $p<0.10$ : a) distribution of Pumping subsystem B efficiency, b) empirical cumulative distribution of Pumping subsystem B efficiency

Basing on the obtained results, it is established that representative efficiency for the last years equals $304000 \mathrm{~m}^{3} / \mathrm{d}$.

\section{Obtained results}

The main research is carried on in three subsequent steps. First is subsystems' reliability analysis, second - subsystems' $L C C$ estimation, third - unit indicator of reliability-cost efficiency calculation for each subsystem.

In reliability analysis authors include all exploitation data regarding the subsystems' elements in order to calculate the values of average operating time between failures and readiness indicator (Tables 3 and 4).

Reliability of Pumping subsystem A

Table 3

\begin{tabular}{|c|c|c|}
\hline Element & $\boldsymbol{T}_{\boldsymbol{p}}[\mathrm{h}]$ & $\boldsymbol{K}[-]$ \\
\hline Pump no. 1 & 208.29 & 0.9326421 \\
\hline Pump no. 2 & 200.54 & 0.9683568 \\
\hline Pump no. 3 & 201.76 & 0.9685216 \\
\hline Pump no. 4 & 203.00 & 0.9687252 \\
\hline Pump no. 5 & 203.00 & 0.9687057 \\
\hline Pump no. 6 & 203.41 & 0.9686958 \\
\hline Pump no. 7 & 211.07 & 0.9678153 \\
\hline Pump no. 8 & 206.12 & 0.9526190 \\
\hline
\end{tabular}

In the Pumping subsystem A there are 4 pumps (no. 1, 2, 3, 4) with design capacity of $138200 \mathrm{~m}^{3} / \mathrm{d}$ each and another 4 pumps (no. 5, 6, 7, 8) with a capacity of $486400 \mathrm{~m}^{3} / \mathrm{d}$ 
each. Pumping subsystem B is equipped with 6 submersible pumps (no. I, II, III, IV, V, VI) with efficiency $120960 \mathrm{~m}^{3} / \mathrm{d}$.

Reliability of Pumping subsystem B

Table 4

\begin{tabular}{|c|c|c|}
\hline Element & $\boldsymbol{T}_{\boldsymbol{p}}[\mathrm{h}]$ & $\boldsymbol{K}[-]$ \\
\hline Pump no. I & 19756.00 & 0.8602282 \\
\hline Pump no. II & 17973.90 & 0.9977346 \\
\hline Pump no. III & 12532.40 & 0.9430728 \\
\hline Pump no. IV & 17973.90 & 0.9977346 \\
\hline Pump no. V & 17973.90 & 0.9977346 \\
\hline Pump no. VI & 17973.90 & 0.9977346 \\
\hline
\end{tabular}

Subsystems' reliability

Table 5

\begin{tabular}{|c|c|c|c|c|}
\hline $\begin{array}{c}\text { Pumping } \\
\text { subsystem }\end{array}$ & Working structure & Working structure in detail & $\boldsymbol{T}_{p}$ [h] & $\boldsymbol{K}$ [-] \\
\hline \multirow{3}{*}{ A } & 2 of 4 \& 1 of 4 & $\begin{array}{c}\text { 2 of pumps no. 1-4 } \\
\text { \& 1 of pumps no. 5-8 }\end{array}$ & 11463.34 & 0.9997736 \\
\cline { 2 - 5 } & 1 of 4 \& 2 of 4 & $\begin{array}{c}\text { 1 of pumps no. 1-4 } \\
\text { \& 2 of pumps no. 5-8 }\end{array}$ & 14347.76 & 0.9998290 \\
\cline { 2 - 5 } & 3 of 4 & 3 of pumps no. 1-4 & 431.53 & 0.9911276 \\
\cline { 2 - 5 } & 4 of 4 & 4 of pumps no. 5-8 & 51.46 & 0.8651493 \\
\hline B & 3 of 6 & 3 of pumps no. 1-6 & 3 997 348.47 & 0.9999905 \\
\hline
\end{tabular}

LCC for both Pumping subsystems

Table 6

\begin{tabular}{|c|c|c|c|c|c|c|c|}
\hline \multirow[b]{2}{*}{ Element } & \multirow[b]{2}{*}{$\begin{array}{c}C_{d} \\
{[\mathrm{PLN}]}\end{array}$} & \multirow[b]{2}{*}{$\begin{array}{c}C_{b} \\
{[\mathrm{PLN}]}\end{array}$} & \multicolumn{2}{|c|}{$C_{u}$} & \multirow[b]{2}{*}{$\begin{array}{c}C_{d i} \\
{[\mathbf{P L N}]}\end{array}$} & \multicolumn{2}{|c|}{$\mathrm{LCC}$} \\
\hline & & & $\begin{array}{c}\text { operation } \\
\text { [PLN] }\end{array}$ & $\begin{array}{c}\text { stand-by } \\
\text { [PLN] }\end{array}$ & & $\begin{array}{c}\text { operation } \\
\text { [PLN] }\end{array}$ & $\begin{array}{c}\text { stand-by } \\
{[\text { PLN] }}\end{array}$ \\
\hline $\begin{array}{l}\text { Building A and } \\
\text { inlet channels }\end{array}$ & 86382 & 1727632 & 1087182 & 1087182 & 32496 & 2933691 & 2933691 \\
\hline Pump no. 1 & 106289 & 2125786 & 40707093 & 434137 & 16415 & 42955584 & 2682628 \\
\hline Pump no. 2 & 106289 & 2125786 & 40707093 & 434137 & 16415 & 42955584 & 2682628 \\
\hline Pump no. 3 & 106289 & 2125786 & 40707093 & 434137 & 16415 & 42955584 & 2682628 \\
\hline Pump no. 4 & 106289 & 2125786 & 40707093 & 434137 & 16415 & 42955584 & 2682628 \\
\hline Pump no. 5 & 61803 & 1236062 & 40538591 & 307034 & 9083 & 41845539 & 1613982 \\
\hline Pump no. 6 & 61803 & 1236062 & 40538591 & 307034 & 9083 & 41845539 & 1613982 \\
\hline Pump no. 7 & 73679 & 1473588 & 24550583 & 340966 & 11316 & 26109167 & 1899550 \\
\hline Pump no. 8 & 73679 & 1473588 & 24550583 & 340966 & 11316 & 26109167 & 1899550 \\
\hline $\begin{array}{l}\text { Building B and } \\
\text { inlet channels }\end{array}$ & 399064 & 7981281 & 7062978 & 7062978 & 176674 & 15619997 & 15619997 \\
\hline Pump no. I & 18999 & 379980 & 9541391 & 76964 & 2993 & 9943363 & 478936 \\
\hline Pump no. II & 18999 & 379980 & 9541391 & 76964 & 2993 & 9943363 & 478936 \\
\hline Pump no. III & 18999 & 379980 & 9541391 & 76964 & 2993 & 9943363 & 478936 \\
\hline Pump no. IV & 18999 & 379980 & 9541391 & 76964 & 2993 & 9943363 & 478936 \\
\hline Pump no. V & 18999 & 379980 & 9541391 & 76964 & 2993 & 9943363 & 478936 \\
\hline Pump no. VI & 18999 & 379980 & 9541391 & 76964 & 2993 & 9943363 & 478936 \\
\hline
\end{tabular}

As stated in point 4, for analysis purposes, subsystems' efficiency equals percentile of 99\% of the recorded efficiencies (Figs. 2b and 4b) ie $207500 \mathrm{~m}^{3} / \mathrm{d}$ for Pumping subsystem A and $304000 \mathrm{~m}^{3} / \mathrm{d}$ for Pumping subsystem B. Minding fact that none of the pumps is 
equipped with frequency converter, to ensure analysed subsystem's efficiency simultaneous work of few of pumps, with design capacity, is required. In other words, sum of operating pumps' capacities has to be equal or higher than analysed subsystem's efficiency.

As analysed subsystems' design capacity is much higher than actual water demand, to obtain analysed subsystems' efficiency some pumps must operate and some would be in stand-by mode. In Table 5 there are presented reliability indicators for every possible working structure of pumping subsystem A \& B which ensure analysed subsystems' efficiencies and involves minimum number of working pumps.

Conducted cost analysis covered investigation of all occurred costs for all pumping subsystems' elements (equation (3)). Each element generates cost during its operation and when it is in stand-by mode. In order to provide full cost analysis authors calculate values of $L C C$ for both states. Discounted $L C C$ values (equations (4) and (5)) are shown in Table 6.

Table 7

$I_{r c e}$ for both Pumping subsystems

\begin{tabular}{|c|c|c|}
\hline Pumping subsystem & Working structure & $\boldsymbol{I}_{\boldsymbol{r c e}}\left[\mathbf{P L N} /\left(\mathbf{m}^{\mathbf{3}} / \mathbf{d}\right)\right]$ \\
\hline \multirow{3}{*}{ A } & 2 of pumps no. 1-4 \& 1 of pumps no. 5-8 & 611 \\
\cline { 2 - 3 } & 1 of pumps no. 1-4 \& 2 of pumps no. 5-8 & 688 \\
\cline { 2 - 3 } & 3 of pumps no. 1-4 & 683 \\
\cline { 2 - 3 } & 4 of pumps no. 5-8 & 630 \\
\hline B & 3 of pumps no. 1-6 & 154 \\
\hline
\end{tabular}

Combined reliability-cost efficiency analysis was based on calculation and interpretation of value of unit indicator of reliability-cost efficiency - $I_{r c e}$ (Table 7).

In case of Pumping subsystem A all four working structure are analysed.

It can be easily seen that operation of pumping subsystem B causes almost four times lower global cost related to the $1 \mathrm{~m}^{3}$.

\section{Summary and conclusions}

In this article, for the first time, authorial combined reliability-cost efficiency analysis is introduced. In order to present the new approach in more comprehensible manner, authors propose new index - unit indicator of reliability-cost efficiency $\left(I_{r c e}\right)$. Analysis of values of this index led to following conclusions:

1. In case of pumping subsystem A, working structure " 2 of pumps no. 1-4 and 1 of pumps no. 5-8" generates the lowest global cost related to the $1 \mathrm{~m}^{3}$ of treated water $\left(611 \mathrm{PLN} /\left(\mathrm{m}^{3} / \mathrm{d}\right)\right)$. This means that it is the least expensive maintenance method for this subsystem.

2. Operation of pumping subsystem B causes almost three times lower global cost $\left(154 \mathrm{PLN} /\left(\mathrm{m}^{3} / \mathrm{d}\right)\right)$ than operation of pumping subsystem A $\left(611-688 \mathrm{PLN} /\left(\mathrm{m}^{3} / \mathrm{d}\right)\right)$. In order to reduce total pumping costs, more optimal operation of pumping subsystem $\mathrm{A}$ should be considered as its operation is more expensive. It would be rational to consider $e g$ equipping engines with frequency converter or consider new pumps' installation in pumping subsystem. Those conclusions can be essential for decisionmaking process for rational management of analysed WTP. 
The reliability-cost efficiency assessment allows to present how operation of each pumping station influenced global operational costs of WTP. What is more, proposed methodology can be easily used for analysing other technical systems.

\section{References}

[1] Batóg B, Batóg J. Analysis of tendencies in households water consumption in Polish cities. J Manage Finance. 2013;11:89-100. http://zif.wzr.pl/pim/2013_3_2_7.pdf.

[2] Grafton RQ, Ward MB, To H, Kompas T. Determinants of residential water consumption: evidence and analysis from a 10-country household survey. Water Resour Res. 2011;47. DOI: 10.1029/2010WR009685.

[3] Zimoch I, Szymik-Gralewska J. Risk assessment methods of water supply system in terms of reliability and operation cost. In: Mambretti S, Brebbia CA, editors. Urban Water II. Southampton: WIT Press; 2014:5162. DOI: 10.2495/UW140051.

[4] Collier C, Jacques D. Optimum equipment life by minimum life cycle costs. J Constr Eng Manage. 1984;10:248-265. DOI: 10.1061/(ASCE)0733-9364(1984)110:2(248).

[5] Reddy VR, Kurian M, Ardakanian R. Life-cycle cost approach for management of environmental resources. A primer. Springer Briefs in Environmental Science 2015. DOI: 10.1007/978-3-319-06287-7.

[6] Ntuen AC. Reliability-based life cycle costing. Microelectron Reliab. 1987;27:833-834. DOI: 10.1016/0026-2714(87)90330-1.

[7] Kong J, Frangopol D. Sensitivity analysis in reliability-based lifetime performance prediction using simulation. J Mater Civ Eng. 2005;17:296-306. DOI: 10.1061/(ASCE)0899-1561(2005)17:3(296).

[8] Kong J, Frangopol D. Cost-reliability interaction in life-cycle cost optimization of deteriorating structures. J Struct Eng. 2004;130:1704-1712. DOI: 10.1061/(ASCE)0733-9445(2004)130:11(1704).

[9] Szymik-Gralewska J, Zimoch I. Optimization of the drinking water coagulation and filtration system as a result of reliability analysis and Life Cycle Costing. In: Nowakowski T, Młyńczak M, Jodejko-Pietruczyk A, Werbińska-Wojciechowska S, editors. Safety and Reliability Methodology and Applications. Taylor \& Francis Group. 2015:487-496. DOI: 10.1201/b17399-71.

[10] Kayid M, Izadkhah S, Alhalees H. Reliability analysis of the proportional mean residual life order. Math Probl Eng. 2014;1-8. DOI: 10.1155/2014/142169.

[11] Shafik RA, Mathew J, Pradhan A. Low-cost unified design methodology for secure test and intellectual property core protection. IEEE Trans Reliab. 2015;64:1243-1253. DOI: 10.1109/TR.2015.2464011.

[12] Liu Y, Zuo MJ, Li YF, Huang HZ. Dynamic reliability assessment for multi-state systems utilizing systemlevel inspection data. IEEE Trans Reliab. 2015;644:1287-1299. DOI: 10.1109/TR.2015.2418294.

[13] Certa A, Enea M, Galante G, Lupo T. A multi-objective approach to optimize a periodic maintenance policy. Int J Reliab, Qual Saf Eng. 2012;19(6). DOI: 10.1142/S0218539312400025.

[14] Safari J. Multi-objective reliability optimization of series-parallel systems with a choice of redundancy strategies. Reliability Eng System Safety. 2012;108:10-20. DOI: 10.1016/j.ress.2012.06.001.

[15] Iwanejko R. Accuracy of reliability measures of water supply and sewage facilities. Scientific Problems Machines Operation Mainten. 2009;1157:29-36. http://t.tribologia.eu/plik/spm/spmom-09v44n1_p-029.pdf.

[16] Niknam SA, Sawhney RA. Model for reliability analysis of multi-state manufacturing systems. Int J Quality Reliab Manage. 2014;31:938-949. DOI: 10.1108/IJQRM-05-2012-0065.

[17] Levitina G, Xinga L, Daia Y. Cold-standby sequencing optimization considering mission cost. Reliab Eng System Safety. 2013;118:28-34. DOI: 10.1016/j.ress.2013.04.010.

[18] Weidea JAM, Pandeyb MD, Noortwijka JM. Discounted cost model for condition-based maintenance optimization. Reliab Eng System Safety. 2010:95;236-246. DOI: 10.1016/j.ress.2009.10.004.

[19] Amani N, Ali NM, Mohammed AH, Samat RA. Maintenance and management of wastewater system components using the condition index system, prediction process and costs estimation. Eksploatacja i Niezawodność - Maintenance Reliab. 2013;15:161-168. http://ein.org.pl/sites/default/files/2013-02-12.pdf.

[20] Kayrbekova D, Barabadi A, Markeset T. Maintenance cost evaluation of a system to be used in Arctic conditions: a case study. J Quality Mainten Eng. 2011;17:320-336. DOI: 10.1108/13552511111180159.

[21] Frangopol DM, Liu M. Maintenance and management of civil infrastructure based on condition, safety, optimization, and life-cycle cost. Struc Infrastruct Eng. 2007;3:29-41, DOI: 10.1080/15732470500253164.

[22] Korpi E, Ala-Risku T. Life cycle costing: A review of published case studies. Managerial Auditing J. 2008;23:240-261. DOI: 10.1108/02686900810857703.

[23] Frangopol DM. Life-cycle performance, management, and optimisation of structural systems under uncertainty: accomplishments and challenges. Struct Infrastruct Eng. 2011;7(6):389-413. DOI: 10.1080/15732471003594427. 
[24] Shafiqul M, Sadiq R, Rodriguez M, Najjaran H, Hoorfar M. Reliability assessment for water supply systems under uncertainties. J Water Resour Plann Manage. 2014;140:468-479. DOI: 10.1061/(ASCE)WR.1943-5452.0000349.

[25] Eisenberg D, Soller J, Sakaji R, Olivieri A. A methodology to evaluate water and wastewater treatment plant reliability. Water Sci Technol. 2001;43:91-99. www.ncbi.nlm.nih.gov/pubmed/11436809.

[26] Woodward D. Life cycle costing - theory. Information acquisition and application. Int J Project Manage. 1997;15:335-344. DOI: 10.1016/S0263-7863(96)00089-0.

[27] Barone G, Frangopol DM. Reliability risk and lifetime distributions as performance indicators for life-cycle maintenance of deteriorating structures. Reliab Eng System Safety. 2014;123:21-37. DOI: 10.1016/j.ress.2013.09.013

[28] Parra C, Crespo A, Cortes P. On the consideration of reliability in the Life Cycle Cost Analysis (LCCA). A review of basic models. In: Soares G, editor. Safety and Reliability for Managing Risk. London: Taylor Francis Group; 2006. http://en.calameo.com/read/0009293100909d00e3b69

[29] Omar MK, Murgan S. An improved model for the cost of quality. Int J Quality Reliab Manage. 2014;31:395-418. DOI: 10.1108/IJQRM-05-2012-0066.

[30] Kumar J, Kadyan MS, Malik SC. Cost analysis of a two-unit cold standby system subject to degradation, inspection and priority. Eksploatacja i Niezawodność - Mainten Reliab. 2012;14:278-283. http://ein.org.pl/sites/default/files/2012-04-03.pdf.

[31] Emblemsvåg J. Activity-based life-cycle costing. Managerial Auditing J. 2001;16:17-27. DOI: $10.1108 / 02686900110363447$.

[32] European Commission. Directorate-General. Regional Policy. Guide to cost-benefit analysis of investment projects. European Commission. Brussels 2008. https://poig.parp.gov.pl/files/74/108/255/3949.pdf. 